\title{
MUHAMMADIYAH DISASTER MANAGEMENT CENTER (MDMC) DALAM PENANGGULANGAN BENCANA BANJIR DI KOTA MAKASSAR
}

\section{MUHAMMADIYAH DISASTER MANAGEMENT CENTER (MDMC) IN FLOOD DISASTER MANAGEMENT IN MAKASSAR CITY}

\author{
Hardianto Hawing \\ Universitas Muhammadiyah Makassar \\ E-mail: hardiantohawing@unismuh.ac.id
}

\begin{abstract}
This article aims to find out how the management of the Muhammadiyah Disaster Management Center (MDMC) in flood disaster management in Makassar City in 2019 and also to find out what factors are hindering the Muhammadiyah Disaster Management Center (MDMC) in flood disaster management in Makassar City in 2019. Type of research which is used is a qualitative research method and the type of research is descriptive. The results showed the Muhammadiyah Disaster Management Center (MDMC) in flood disaster management in Makassar City in 2019 from four indicators, namely Mitigation, where mitigation in this case is the effort made in the process of disaster management. In terms of mitigation, MDMC is not well realized because it is the responsibility of the government. Preparedness, in terms of preparedness MDMC is always ready to handle flood disasters in the city of Makassar. This can be seen from the level of seriousness of MDMC in handling flood disasters in the city of Makassar. Emergency response, MDMC is always responsive to disasters that will occur, prepare whatever is needed during the implementation and so on. Rehabilitation, in this case MDMC provides assistance in the form of health, education, helping the community, in this case mothers and children, to relieve their sense of comfort after a disaster. In disaster management, everything did not go smoothly according to what was thought. There were several obstacles faced by MDMC, including the lack of resources (human resources, equipment used, and financial resources), the next obstacle was the lack of public awareness.
\end{abstract}

Keywords: disaster management; natural disasters; flood

\begin{abstract}
ABSTRAK
Penelitian ini bertujuan untuk mengetahui bagaimana pengelolaan Muhammadiyah Disaster Management Center (MDMC) dalam penanggulangan bencana banjir di Kota Makassar tahun 2019 dan juga untuk mengetahui faktorfaktor apa saja yang menghambat Muhammadiyah Disaster Management Center (MDMC) dalam penanggulangan bencana banjir di kota Makassar Tahun 2019. Jenis penelitian yang digunakan adalah metode penelitian kualitatif dan jenis
\end{abstract}

Journal of Governance and Local Politics (JGLP)

ISSN (online): 2684-9992, Volume: 3, Nomor: 1, Mei 2021 
penelitiannya deskriptif. Hasil penelitian menunjukkan Muhammadiyah Disaster Management Center (MDMC) dalam penanggulangan bencana banjir di Kota Makassar tahun 2019 dari empat indikator yaitu Mitigasi, dimana mitigasi dalam hal ini merupakan upaya yang dilakukan dalam proses penanggulangan bencana. Dari sisi mitigasi, MDMC belum terealisasi dengan baik karena menjadi tanggung jawab pemerintah. Kesiapsiagaan, dari segi kesiapsiagaan MDMC selalu siap menangani bencana banjir di Kota Makassar. Hal ini terlihat dari tingkat keseriusan MDMC dalam menangani bencana banjir di Kota Makassar. Tanggap darurat, MDMC selalu tanggap terhadap bencana yang akan terjadi, mempersiapkan apa saja yang dibutuhkan selama pelaksanaan dan sebagainya. Rehabilitasi, dalam hal ini MDMC memberikan bantuan berupa kesehatan, pendidikan, membantu masyarakat dalam hal ini ibu dan anak untuk meringankan rasa nyamannya pascabencana. Dalam penanggulangan bencana, semuanya tidak berjalan mulus sesuai dengan yang dipikirkan. Ada beberapa kendala yang dihadapi oleh MDMC antara lain kurangnya sumber daya (sumber daya manusia, peralatan yang digunakan, dan sumber daya keuangan), kendala berikutnya adalah kurangnya kesadaran masyarakat.

Kata kunci: manajemen bencana; bencana alam; banjir

\section{PENDAHULUAN}

Bencana di Indonesia menjadi perhatian penting pemerintah, utamanya setelah terjadinya Gempa dan Tsunami di Aceh (Srikandini, Hilhorst, \& Voorst, 2018). Dalam Undang-Undang No 24 tahun 2007 Pasal 1 tentang penanggulangan bencana, telah dikemukakan bahwa "Bencana adalah peristiwa atau rangkaian peristiwa yang mengancam dan mengganggu kehidupan dan penghidupan masyarakat, sehingga mengakibatkan timbulnya korban jiwa manusia, kerusakan lingkungan, kerugian harta benda, dan dampak psikologis" (Kusumasari, 2019). Terdapat tiga jenis bencana dalam pasal 1 Undang-Undang Nomor 24 tahun 2007 yaitu, bencana alam, bencana non alam, dan bencana sosial. Bencana alam merupakan kejadian atau peristiwa yang berasal dari alam, seperti gempa bumi, tsunami, banjir, dan tanah longsor. Bencana non alam merupakan kejadian atau peristiwa yang meliputi kegagalan teknologi dan wabah penyakit. Bencana sosial merupakan kejadian atau peristiwa yang dibuat atau berasal dari masyarakat itu sendiri, seperti teror atau konflik antar 
kelompok. Bencana terjadi tidak hanya sekali tetapi berulang kali, maka penanganan bencana menjadi sangat penting untuk menjadi perhatian dan tugas kita bersama. Pengurangan risiko bencana dan dampak akibat bencana yang terjadi bisa diminimalisir dengan manajemen yang baik (Kusumasari, 2019).

Dalam manajemen risiko bencana dikenal juga dasar pendekatan dan proses-proses manajemen seperti ketidakpastian, penilaian terhadap kemungkinan terjadinya bencana, besaran bahaya, dampak yang disesbabkan, evaluasi dan bagaimana bahaya tersebut dikelola sejak sebelum, pada saat, dan setelah bencana (Couch, 2008). Dalam pelaksanaan mitigasi dan penanggulangan bencana, tidak hanya sekedar pemerintah yang dapat melakukan tindakan. Gerakan sosial yang fokus pada masalah kebencanaan pun diberi hak dan kesempatan untuk melakukan tindakan tersebut (Ginanjar \& Mubarrok, 2020).

Meskipun Badan Nasional Penanggulangan Bencana (BNPB) merupakan lembaga pemerintah yang bertugas menangani tentang kebencanaan, tidak menutup kemungkinan untuk gerakan sosial lain dapat bermitra untuk tindakan cepat pada kejadian-kejadian luar biasa yang bersifat kebencanaan. Pemerintah merupakan penanggung jawab inti dalam pelaksanaan penanggulangan bencana dan gerakan sosial kebencanaan merupakan kekuatan luar biasa dalam pelaksanaan penanggulangan dan mitigasi bencana.

Salah satu organisasi kemanusiaan nasional di bawah naungan organisasi sosial yang sampai saat ini masih eksis serta memiliki andil dalam penanggulangan bencana yaitu MDMC (Muhamadiyah Disaster Management Center) (Baidhawy, 2015). Muhammadiyah Disaster Management Center (MDMC) mengambil bagian sebagai lembaga penanggulangan bencana untuk membantu masyarakat mulai dari pra bencana, tanggap darurat dan pasca bencana. Di dalam penanganan bencana terdapat beberapa aspek yaitu aspek mitigasi 
bencana (pencegahan), kegawatdaruratan saat terjadinya bencana, dan aspek rehabilitasi (Baidhawy, 2015).

Penanganan kegawatdaruratan targetnya adalah penyelamatan sehingga resiko tereliminir. Sedangkan rehabilitasi merupakan upaya mengembalikan pada kondisi normal kembali. Di Sulawesi Selatan sering terjadi bencana alam. Bencana alam yang sering terjadi setiap tahunnya adalah bencana banjir namun banjir sulawesi selatan terparah dalam satu dekade terakhir yang terjadi adalah pada tahun 2019. . Bencana alam ini terjadi pada musim hujan, akibat dari bencana ini berdampak pada kehidupan sosial masyarakat di sekitarnya, seperti halnya akses perekonomian terhambat, pendidikan terganggu, kesehatan menurun, dan akibat bencana alam tersebut terkadang melahirkan korban jiwa bahkan sampai mengakibatkan kematian. Salah satu daerah yang merupakan langganan setiap tahunnya terjadi bencana ini adalah Kota Makassar yang juga merupakan ibukota dari provinsi tersebut.

Salah satu organisasi masyarakat yang merespon bencana alam salah satunya bencana banjir adalah Organisasi Muhammadiyah yaitu lembaga tersebut dinamakan Muhammadiyah Disaster Management Center atau yang disingkat MDMC. Kehadiran lembaga ini merupakan respon terhadap kepedulian organisasi Muhammadiyah kepada masyarakat atas peristiwa-peristiwa yang mengganggu kehidupan masyarakat akibat dampak yang terjadi diakibatkan oleh faktor Alam. Berdasarkan paparan tersebut maka tujuan penelitian ini adalah untuk menganalisa peran Muhammadiyh Disaster Managemen Center (MDMC) dalam penanggulangan bencana banjir di kota Makassar tahun 2019.

\section{METODE PENELITIAN}

Jenis penelitian ini adalah penelitian deskriptif kualitatif yakni suatu bentuk penelitian yang bertujuan untuk memberikan gambaran umum berbagai 
macam data yang dikumpulkan dari lapangan secara objektif berkaitan dengan objek penelitian tentang Muhammadiyah Disaster Management Centre (MDMC).

Sumber data, data primer, yaitu data hasil penelitian yang diperoleh melalui wawancara dan pengamatan langsung terhadap objek yang di teliti. data sekunder, yakni data yang diperoleh dari sumber lain, dari dokumen dan bahan bacaan lainnya yang berhubungan dengan obyek penelitian (Moleong, 2010).

\section{HASIL DAN DISKUSI}

Lembaga Penanggulangan Bencana Muhammadiyah atau yang dikenal dengan Muhammadiyah MDMC Indonesia berdiri pada tahun 2007 dengan nama pusat penanggulangan bencana, yang kemudian dikukuhkan menjadi lembaga yang bertugas mengkoordinasikan sumber daya Muhammadiyah dalam kegiatan penanggulangan bencana oleh Pimpinan Pusat Muhammadiyah Pasca Muktamar tahun 2010 (Hilman, 2018). MDMC mengembang misi pengurangan resiko bencana dengan empat aspek yaitu mitigasi, kesiapsiagaan, tanggap darurat, dan rehabilitasi, serta mengembangkan basis kesiapsiagaan di tingkat komunitas, sekolah, dan rumah sakit sebagai basis gerakan Muhammadiyah (Rokib, 2012).

Kota Makassar adalah salah satu wilayah di sulawesi selatan dengan potensi indeks rawan banjir (Haslinda B. Anriani, Ansar Arifin, Harifuddin Halim, Rasyidah Zainuddin, \& Abdul Malik Iskandar, 2019). Di setiap tahunya saat musim hujan terjadi, banjir semakin meningkat di wilayah-wilayah tertentu di daerah makassar (Muh. Iqbal Latief, Sultan Djibe, \& Arsyad Genda, 2019). Salah satu organisasi masyarakat yang merespon benncana alam salah satunya bencana banjir adalah organisasi Muhammadiyah yaitu lembaga yang di namakan Muhammadiyah Disaster Management Center (MDMC). Kehadiran lembaga ini merupakan respon terhadap kepedulian organisasi Muhammadiyah kepada masyarakat atas peristiwa-peristiwa yang mengganggu kehidupan masyarakat akibat dampak yang terjadi yang di akibatkan oleh faktor alam 
untuk meninjau dan mengetahui lebih lanjut peran Muhammadiyah disaster Management Centre dalam penanggulangan bencna banjir di kota Makassar telah melakukan tahap-tahap di antaranya adalah mitigasi, kontinjensi, operasi, pemulihan.

\section{Mitigasi}

Mitigasi merupakan sesuatu upaya yang dilakukan untuk mengurangi dan menghapus kerugian dan korban yang mungkin terjadi akibat bencana (Kusumastuti, Viverita, Husodo, Suardi, \& Danarsari, 2014). Hal ini sangat di perlukan dalam lembaga atau organisasi dalam manajemen penanggulangan bencana, adapun tujuan dari mitigasi itu sendiri yaitu untuk mengurangi kerugian-kerugian pada saat terjadinya bahaya pada masa yang akan datang dengan mengurangi risiko kematian dan cedera terhadap penduduk serta pengurangan infrastruktur dan sektor publik (Adi, 2014). Mitigasi bencana merupakan suatu serangkaian upaya untuk mengurangi resiko bencana, baik melalui pembangunan fisik, maupun penyadaran dan peningkatan kemampuan menghadapi ancaman bencana. Mitigasi bencana adalah upaya untuk mencegah atau mengurangi dampak yang ditimbulkan akibat suatu bencana, sehingga jelas bahwa mitigasi bersifat pencegahan sebelum kejadian. Adapun salah satu contoh tugas dari pemerintah yaitu, membuat tanggul untuk mencegah naiknya air di permukaan, serta memasang sistem pemantauan dan peringatan dini didaerah rawan banjir, sedangkan contoh dari MDMC yaitu, menumbuhkan kesadaran masyarakat untuk menjaga lingkungan, pendekatan kepada masyarakat serta memberikan pendidikan dan penguatan kapasitas masyarakat,

\section{Kontinjensi (Kesiapsiagaan)}

Kontinjensi merupakan tahap pra bencana dalam situasi terdapat potensi bencana dilakukan penyusunan rencana kesiapsiagaan untuk meghadapi keadaan darurat yang didasarkan atas skenario menghadadapi bencana tertentu (single hasard) maka disusun satu rencana yang disebut rencana kontinjensi 
(Contigenty plan) (Khaerah, Harakan, \& Junaedi, 2019). kesiap siagaan adalah serangkaian kegiatan yang dilakukan untuk mengantisipasi bencana melalui pengorganisasiam serta melalui langkah yang tepat guna dan berdaya guna (Sugiyanto, 2009). Kesiapsiagaan adalah tahapan yang paling strategis karena sangat menentukan ketahanan anggota masyarakat dalam menghadapi datangnya suatu bencana (Sugiyanto, 2009). Adapun salah satu contoh tugas dari pemerintah yaitu memberikan perlindungan kepada masyarakat dari ancaman bencana, mengingatkan seluruh aparatur pemerintah daerah dan mengkoordinasikan dengan TNI, Polri, Institusi vertikal di daerah dan relawan siaga, membentuk posko kesiapsiagaan pemerintah daerah dan melakukan pemantaun dini dari BMKG, BNPB dan Pusat Vulkanologi dan Mitigasi Bencana Geologi untuk mengetahui perkembangan situasi terkini, sedangkan contoh dari MDMC yaitu, memberikan peringatan langsumg kepada masyarakat, memberikan sosialisasi tentang hal apa yang akan dilakukan dalam bersiapsaiga ketika aka terjadi bencana, melakukan perlombaan tentang cerdas tanggap bencana.

\section{Operasi (Tanggap Darurat)}

Operasi pada saat tanggap darurat dilakukan rencana operasi (operational plan) yang merupakan operasionalisasi atau aktifasi dari rencana kedaruratan atau rencana kontijensi yang telah disusun sebelumnya (Muh. Iqbal Latief et al., 2019). Namun, pada dasarnya konsep dan muatan antara rencana kontinjensi dan operasi adalah sama. Hal yang membedakan antara dua perencanaan tersebut, yaitu waktu penyusunan. Rencana kontinjensis disusun menjelang dan sebelum terjadi bencana sehingga rencana disusun berdasarkan asumsi dan skenario.

Tanggap darurat bencana merupakan serangkaian kegiatan yang dilakukan dengan segera pada saat kejadian bencana untuk menangani dampak buruk yang di timbulkan, yang meliputi kegiatan penyelamatan dan evakuasi 
korban, harta benda, pemenuhan kebutuhan dasar, perlindungan, pengurusan pengungsi, penyelamatan serta pemulihan sarana dan prasarana. Adapun salah satu contoh tugas dari pemerintah yaitu, mengalokasikan anggaran belanja tidak terduga (BTT) yang cukup dan siap di gunakan setiap saat dalam keadaan darurat bencana, penyelamatan dan evaluasi apabila terjadi kondisi darurat serta mengaktifkan rencana kontinjensi yang disusun jika terjadi tanggap darurat, sedangkan contoh dari MDMC yaitu, melakukan pengkajian secara cepat dan tepat terhadap lokasi, kerusakan, kerugian dan sumberdaya, Menyelamatkan dan mengevakuasi masyarakat yang terkena bencana.

\section{Rehabilitasi}

Setelah penanganan kejadian bencana, tahap pengelolaan bencana selanjutnya adalah rehabilitasi. Rehabilitasi mengacu kearah pemulihan sarana dan prasanan masyarakat yang rusak sehingga dapat di fungsikan kembali. Pemulihan pada tahap ini dilakukan penyususnan rencana pemulihan (recovery plan) yang meliputi rencana rehabilitasi dan rekonstruksi yang dilakukan pascabencana. Sedangkan jika bencana belum terjadi, untuk mengantisipasi kejadian bencana pada masa mendatan dilakukan penyusunan petunjuk/pedoman maupun mekanisme penanggulangan pasca bencana (Suleman \& Apsari, 2017). Adapun salah satu contoh tugas dari pemerintah yaitu, perbaikan lingkungan daerah, perbaikan sarana dan prasarana umum, pemulihan ekonomi, sosial dan budaya, sedangkan contoh dari MDMC yaitu, pemulihan trauma yang terjadi pada orang tua dan anak-anak, memberikan bantuan pelayanan kesehatan, Memberikan pendidikan.

Dalam pelaksanaan penanggulangan bencana, banyak faktor-faktor menjadi penghambat sehingga peroses pelaksanaan penanggulangan bencana itu tidak berjalan sesuai dengan apa yang diharapkan. Dalam pelaksanaannya, MDMC juga mengalami banyak hambatan sehingga dalam peroses pelaksanaan 
pengendalian bencana tidak berjalan sesuai dengan mestinya. Faktor-faktor yang penghambat dalam pelaksanaannya adalah :

1. Terbatasnya sumber daya, Sumber daya yang di maksud adalah sumber daya manusia, sarana dan prasarana dan juga sumber daya uang (pendanaan). Sarana dan prasarana yang ada sangat terbatas, selain itu keseluruhan pendanaan yang digunakan hanya berasal dari sumbangan dan juga uang pribadi

2. Rendahnya kesadaran dari masyarakat, meskipun sebagaian masyarakat sadar akan pentingny pencegahan sebelum terjadinya bencana, tetapi masih banyak masyarakat yang kurang menyadari pentingnya pencegahan bencana sebelum terjadi.

\section{KESIMPULAN}

Berdasarkan hasil penelitian yang dilakukan penulis dengan judul muhammadiyah disaster management center ( $m d m c)$ dalam penanggulangan bencana banjir di kota makassar tahun 2019 ada beberapa hal yang menjadi kesimpulan yaitu Muhammadiyah disaster management center ( $m d m c$ ) dalam penanggulangan bencana banjir di kota makassar tahun 2019 dari ke empat indikator yaitu:

1. Mitigasi yakni bagaimana MDMC berperan dalam penanganan bencana, meskipun pada indikator ini MDMC tidak terlalu terlibat langsung karna itu menjadi tugas dan wewenang dari pemerintah.

2. Kesiapsiagaan, dalam indikator ini MDMC siap siaga dalam penanganan bencana banjir, baik pada sebelum terjadinya banjir dan saat terjadi dan pada saat setelah terjadinya banjir.

3. Tanggap Darurat, pada tahapan ini, MDMC berperan aktif dalam penanganan bencana, sebelum terjadinya bencana dan telah ada tandatanda akan terjadi bencana MDMC telah memberikan himbauan lansung 
kepada masyarakat. Dan pada saat bencana terjadi MDMC turut lansung dalam peroses pengevakuasian korban bencana. (4) Rehabilitasi, pada tahapan ini MDMC memberikan bantuan kemanusian kepada korban bencana, baik berupa bantuan kesehatan, pendidikan, tempat pengunsian, dan lain-lain.

Meskipun dalam tahapan ini, MDMC tidak mampu memberikan bantuan sesuai dengan penjelasan dari Indikator Rehabilitasi karena itu memang bukan ranah dari MDMC tetapi menjadi tugas dari pemerintah pusat dan pemerintah daerah yakni memperbaiki kembali gedung-gedung atau bagunan-bangunan pelanyanan masyarakat yang tertimpah banjir.

\section{DAFTAR PUSTAKA}

Adi, S. (2014). KARAKTERISASI BENCANA BANJIR BANDANG DI INDONESIA. Jurnal Sains Dan Teknologi Indonesia, 15(1). https://doi.org/10.29122/jsti.v15i1.938

Baidhawy, Z. (2015). The role of faith-based organization in coping with disaster management and mitigation Muhammadiyah's experience. Journal of Indonesian Islam. https://doi.org/10.15642/JIIS.2015.9.2.167-194

Couch, S. R. (2008). Handbook of Disaster Research. Contemporary Sociology: A Journal of Reviews, $\quad 37(2), \quad 146-147$. https://doi.org/10.1177/009430610803700227

Ginanjar, W. R., \& Mubarrok, A. Z. (2020). Civil Society and Global Governance: The Indirect Participation of Extinction Rebellion in Global Governance on Climate Change. Journal of Contemporary Governance and Public Policy, 1(1), 41-52. https://doi.org/https://doi.org/10.46507/jcgpp.v1i1.8

Haslinda B. Anriani, Ansar Arifin, Harifuddin Halim, Rasyidah Zainuddin, \& Abdul Malik Iskandar. (2019). Bencana Banjir dan Kebijakan Pembangunan Perumahan Di Kota Makassar. Talenta Conference Series: Local Wisdom, 
Social, and Arts (LWSA), 2(1), 1-7. https://doi.org/10.32734/lwsa.v2i1.599

Hilman, Y. A. (2018). Disaster Management Concept of Muhammadiyah Disaster Management Centre in Ponorogo, Indonesia. Otoritas: Jurnal Ilmu Pemerintahan, 8(1), 65. https://doi.org/10.26618/ojip.v8i1.807

Khaerah, N., Harakan, A., \& Junaedi, J. (2019). Call Centre Brigade Siaga Bencana Sebagai Strategi Pelayanan Kesehatan di Kabupaten Bantaeng. JDP (JURNAL DINAMIKA PEMERINTAHAN), 2(1), 51-64. https://doi.org/10.36341/jdp.v2i1.736

Kusumasari, B. (2019). Natural Hazards Governance in Indonesia. Oxford Research Encyclopedia of Natural Hazard Science. Oxford University Press. https://doi.org/10.1093/acrefore/9780199389407.013.234

Kusumastuti, R. D., Viverita, Husodo, Z. A., Suardi, L., \& Danarsari, D. N. (2014). Developing a resilience index towards natural disasters in Indonesia. International Journal of Disaster Risk Reduction, 10, 327-340. https://doi.org/10.1016/j.ijdrr.2014.10.007

Moleong, L. J. (2010). Metodologi penelitian kualitatif. Bandung: Remaja Rosdakarya.

Muh. Iqbal Latief, Sultan Djibe, \& Arsyad Genda. (2019). Manajemen Risiko Berbasis Kelompok Sadar Bencana di Sulawesi Selatan. Talenta Conference Series: Local Wisdom, Social, and Arts (LWSA), 2(1), 1-6. https://doi.org/10.32734/lwsa.v2i1.611

Rokib, M. (2012). The Importance of Faith-Based Organization in Shaping Natural Disaster: Case Study of Muhammadiyah. SALAM Jurnal Study Masyarakat Islam, 15(2).

Srikandini, A. G., Hilhorst, D., \& Voorst, R. Van. (2018). Disaster Risk Governance in Indonesia and Myanmar: The Practice of Co-Governance. Politics and Governance. Cogitatio. https://doi.org/10.17645/pag.v6i3.1598

Sugiyanto, S. (2009). KESIAP-SIAGAAN MASYARAKAT DALAM PENGELOLAAN 
BEnCANA ALAM - Kasus di Si Tellu Tali Urang Jehe. Jurnal Penelitian Dan $\begin{array}{llll}\text { Pengembangan } \quad \text { Kesejahteraan } & \text { Sosial, }\end{array}$ https://doi.org/https://doi.org/10.33007/ska.v14i2.733

Suleman, S. A., \& Apsari, N. C. (2017). PERAN STAKEHOLDER DALAM MANAJEMEN BENCANA BANJIR. Prosiding Penelitian Dan Pengabdian Kepada Masyarakat. https://doi.org/10.24198/jppm.v4i1.14210 